補緅誌, J Jpn Prosthodont Soc, 33 : 571 576, 1989.

原著論文

\title{
床用レジンの口腔内主要構成細菌に対する抗菌性
}

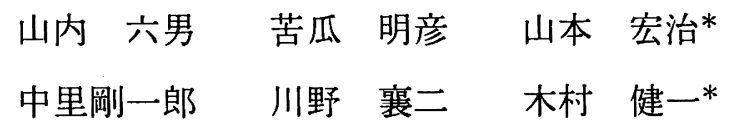

\section{Antibacterial Actions of Denture Base Resin on Oral Bacteria}

\author{
Mutsuo Yamauchi, Akihiko Nigauri, Kohji Yamamoto*, \\ Gohichiro Nakazato, Joji Kawano and Kenichi Kimura*
}

\begin{abstract}
Antibacterial action of various denture base resins on thirteen species of bacteria were studied in vitro. Antibacterial effect of $5 \%$ tannin-fluoride preparation, $5 \%$ tannic acid and $5 \%$ chlorhexidine added to resins on these thirteen bacterial species were also investigated using heat-curing denture base resins.

Fresh microwave-curing resin and pour-type resin each showed an antibacterial action on one bacterial strain. Fresh self-curing resins had antibacterial actions on serveral bacterial strains. However, after storage in water at $37^{\circ} \mathrm{C}$ for one week, antibacterial action of microwave-curing and pour-type resin were diminished and self-curing resins partially lost their antibacterial actions.

Denture base resin containing tannin-fluoride preparation or tannic acid showed an antibacterial effect on one bacterial strain. On the other hand, denture base resin containing chlorhexidine had an antibacterial action on eleven bacterial strains. However, color and mechanical properties of the drug-containing resins were not satisfactory.
\end{abstract}

Key words : denture base resin, antibacterial action, oral bacteria, chlorhexidine

\section{I. 緒言}

従来から，義歯性口内炎や支台歯の歯周疾患に関連し て, 床用レジンや粘膜調整材の抗菌性 ${ }^{1)}$ あるいは床用レ ジンへの薬剤添加による物性 ${ }^{2 \sim 4)}$ や抗菌性への影響 ${ }^{\text {( 7), }}$,

朝日大学歯学部歯科補緅学第 1 講座 (主任 : 川野襄二教授)

* 朝日大学歯学部歯科保存学第 1 講座 (主任 : 木村健一教授) First Department of Prosthodontics Asahi University, School of Dentistry (Chief : Prof. Joji Kawano)

* Department of Operative Dentistry Asahi University, School of Dentistry (Chief : Prof. Kenichi Kimura)

昭和 63 年 12 月 16 日受付
粘膜調整材への薬剤添加による抗菌性 ${ }^{8 \sim 11)}$ などについて 検討されている. しかしながら，供試している床用レジ ンも少なく, 義歯性口内炎, 鉤歯のう触や歯周疾患予防 などを考えると, 口腔内の主要構成細菌種に対する抗菌 性を調へる必要があると考えられる.

そこでわれわれは，まず市販されている主な床用レジ ンについて, 口腔内主要構成細菌に対する抗菌性を検討 することにした. また, 従来から床用レジンへの添加が 行われている数種の薬用2,4 7)について, 床用レジンへの 添加後の抗菌性に関しても検討した. 
表 1 実験に用いた床用レジン

\begin{tabular}{|c|c|c|c|}
\hline 重合形式 & 㫦品名 & 製造会社 & バッチナンバー \\
\hline $\begin{array}{l}\text { 加熱重合 } \\
\text { レジン }\end{array}$ & $\begin{array}{l}\text { アクロン } \\
\text { アタロン } \mathrm{MC}^{*} \\
\text { メタデント }\end{array}$ & $\begin{array}{l}\text { 而至菡科工業 } \\
\text { 而至菌科工業 } \\
\text { サンメディカル }\end{array}$ & $\begin{array}{l}\text { P }: 091231 \\
\text { L }: 310871 \\
\text { P }: 061071 \\
\text { L }: 160971 \\
P: 10902 \\
L: 11101\end{array}$ \\
\hline $\begin{array}{l}\text { 常温重台 } \\
\text { レジン }\end{array}$ & $\begin{array}{l}\text { リペロン } \\
\text { クールライナー } \\
\text { パラベース }\end{array}$ & $\begin{array}{c}\text { 而至惟科工棠 } \\
\text { カー } \\
\text { クルツァー }\end{array}$ & $\begin{array}{l}P: 160471 \\
\text { L }: 180571 \\
P: 072485 B \\
L: 092785 A \\
P: 2100205 \\
L: 2100176\end{array}$ \\
\hline $\begin{array}{l}\text { 流し込み } \\
\text { レジン }\end{array}$ & ハシラプレス & クルツァー & $\begin{array}{l}\mathrm{P}: 7008732 \\
\mathrm{~L}: 7080424\end{array}$ \\
\hline
\end{tabular}

P : Powder L : Liquid *: アイクロ波重合

\section{II. 実験材料および方法}

実験には, 加熱重合レジン 3 種, 常温重 合レジン 3 種, 流し込みレジン 1 種の計 7 種の床用レジンを用いた (表 1). これらのレジンを金型を用い, 直径 $9 \mathrm{~mm}$, 厚 さ $1 \mathrm{~mm}$ の円盤状にメーカー指示に従い重合し, バリ や石玄などを除去した後, 24 時間室温に保管したもの と, $37^{\circ} \mathrm{C}$ の水中に 1 週間浸漬したものを試料とした.さ らに, タンニンフッ化物 ${ }^{4,12)}$ (以下, HY 材と略す), 夕 ンニン酸6)，クロールヘキシジン $(\mathrm{ICI} \text { 社 })^{2,5,7)}$ の 3 種の 薬剤を, アクロン MC に重量 \% で 5\% 添加し, 重合 直後の抗菌性について検討した.

供試菌株には, 口腔内主要構成細菌であり，う蝕，歯 周疾患および義歯性口内炎との関連が深い 8 種の基準株 および 5 種の臨床分離株の計 13 菌種を用いた (表 2).

抗菌性試験は, 偏性嫌気性菌については WilkinsChalgren broth で一夜培荃した後, 菌液の $0.1 \mathrm{ml}$ を Prereduced CDC anaerobe blood agar に滴下し, 塗抹 拉散後, 平板上にレジンを静置した. 通性嫌気性菌は 0.5 $\%$ yeast extract (Difco 社) を含む Trypticase soy broth (BBL 社以下,TSB と略す)で一夜培羕した後, 菌液 の $0.1 \mathrm{ml}$ を TSB に $0.5 \%$ yeast extract と $1 \%$ agar を加えた平板上に滴下し, 塗抹拡散後, レジンを静置し た. 抗菌性試験用平板は $37^{\circ} \mathrm{C} て ゙ ~ 48$ 時間嫌気培養した 後, 阻止帯を測定した ${ }^{13)}$. ただし，C. albicans は sabouraud 寒天培地 (日水社) を用いて好気培養を行った.

阻止帯の测定はノギスで各 4 点の阻止帯を測定し 1 $\mathrm{mm}$ 以下を 一, 1〜3 $\mathrm{mm}$ を,$+ 3 \sim 5 \mathrm{~mm}$ をH, $5 \mathrm{~mm}$ 以上を冊と判定した.
表 2 供試菌株

\begin{tabular}{ll}
\hline \hline Streptococcus mutans & ATCC 15475 \\
Streptococcus sanguis & ATCC 10556 \\
Streptococcus oralis & ATCC 35037 \\
Streptococcus mitis & ATCC 33399 \\
Streptococcus salivarius & ATCC 25975 \\
Bacteroides intermedius & ATCC 15032 \\
Bacteroides gingivalis & ATCC 33277 \\
Eubacterium & clinical \\
Peptostreptococcus & clinical \\
Fusobacterium & clinical, \\
Veillonella & clinical \\
Actinomyces viscosus & clinical \\
Candida albicans & IFO 1060 \\
\hline
\end{tabular}

\section{III. 実験結果}

\section{1. 重合直後の床用レジンの抗菌性}

図 1 に S. salivarius に対する抗菌性の 1 例と, C. albicans に対する抗菌性の 1 例を示した. リベロンではかな り大きな阻止帯がみられ，卅と判定した. アクロン MC では約 $1 \mathrm{~mm}$ の阻止帯がみられ，十と判定した.

表 3 に重合直後のレジンの抗菌性試験の結果を示し た. S. mutans, S. oralis, S. mitis, B. intermedius, Eubacterium, Peptostreptococcus, Fusobacterium, Veillonella, A. viscosus に対しては, すべてのレジンにおいて抗 菌性を示さなかった. また, 抗菌性を示すレジンでも 1 菌種ないし 3 菌種にしか抗菌性を示さなかった. すなわ ち, S. sanguis とS. salivarius に対してはリベロン，ク ールライナー, パラベースが, B. gingivalis に対しては パラベースとパラプレスが, C. albicans に対してはアク ロン MC が抗菌性を示した.

\section{2. 水中浸漬後の床用レジンの抗菌性}

$37^{\circ} \mathrm{C}$ 水中に 1 週間浸漬したレジンの抗菌性の結果を 表 4 に示した. アクロン MC では C. albicans に対し水 中浸漬により抗菌性を示さなくなった. リベロンでは S. salivarius に対して抗菌性を示さなくなり，パラベー スとパラプレスでは B. gingivalis に対して抗菌性を示 さなかった。

\section{3. 薬骩添加による休用レジンの抗菌性}

図 2 に S. mutans, S. sanguis, S. mitis に対する抗菌 性の結果の 1 例を示した.

表 5 に各供試菌に対する抗菌性の結果を示した. HY 材添加では Fusobacterium, タンニン酸添加では $C$. 

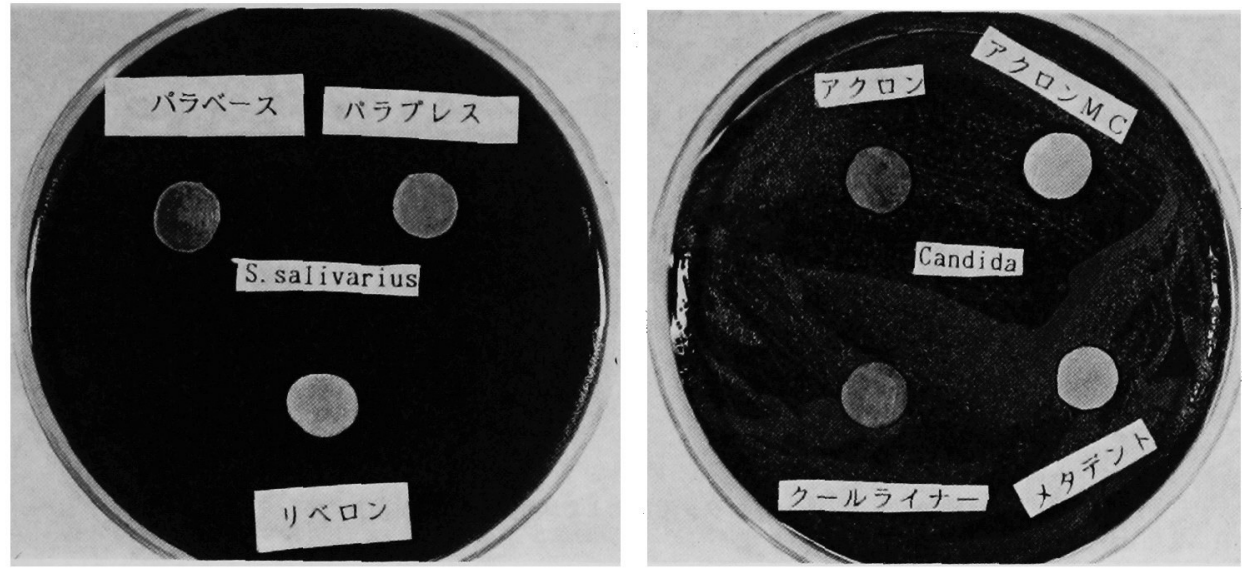

図 1 重合直後の床用レジンの抗菌性の例

表 3 重合直後の床用レジンの抗菌性

\begin{tabular}{|c|c|c|c|c|c|c|c|}
\hline \multirow{2}{*}{ 菌種 } & \multicolumn{3}{|c|}{ 加熱重合 レジン } & \multicolumn{3}{|c|}{ 常 温重 合 レ ジン } & 流し込みレジン \\
\hline & アクロン & アクロン MC & メタデント & リベロン & タールライナー & パラペース & パラフレス \\
\hline S. mutans & - & - & - & - & - & - & - \\
\hline S. sanguis & - & - & - & + & + & + & - \\
\hline S. oralis & - & - & - & - & - & - & - \\
\hline S. mitis & - & - & - & - & - & - & - \\
\hline S. salivarius & - & - & - & \# & + & + & - \\
\hline B. intermedius & - & - & - & - & - & - & - \\
\hline B. gingivalis & - & - & - & - & - & + & + \\
\hline Eubacterium & - & - & - & - & - & - & - \\
\hline Peptostreptococcts & - & - & - & - & - & - & - \\
\hline Fusobacterium & - & - & - & - & - & - & - \\
\hline Veillonella & - & - & - & - & - & - & - \\
\hline A. viscostts & - & - & - & - & - & - & - \\
\hline C. albicans & - & + & - & - & - & - & - \\
\hline
\end{tabular}

表 4 水中浸漬後の床用レジンの抗菌性

\begin{tabular}{|c|c|c|c|c|c|c|c|}
\hline \multirow{2}{*}{ 菌種 } & \multicolumn{3}{|c|}{ 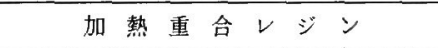 } & \multicolumn{3}{|c|}{ 常 温 重 合レジン } & \multirow{2}{*}{\begin{tabular}{|c|} 
流し込みレジン \\
パラプレス
\end{tabular}} \\
\hline & アクロン & アクロン MC & メタデント & リベロン & タールライナー & パラベース & \\
\hline S. mutans & - & - & - & - & - & - & - \\
\hline S. sanguis & - & - & - & + & + & + & - \\
\hline S. oralis & - & - & - & - & - & - & - \\
\hline S. mitis & - & - & - & - & - & - & - \\
\hline S. salivarius & - & - & - & - & + & + & - \\
\hline B. intermedius & - & - & - & - & - & - & - \\
\hline B. gingivalis & - & - & - & - & - & - & - \\
\hline Eubacterium & - & - & - & - & - & - & - \\
\hline Peptostreptococcus & - & - & - & - & - & - & - \\
\hline Fusobacterium & - & - & - & - & - & - & - \\
\hline Veillonella & - & - & - & - & - & - & - \\
\hline A. viscosus & - & - & - & - & - & - & - \\
\hline C. albicans & - & - & - & - & - & - & - \\
\hline
\end{tabular}




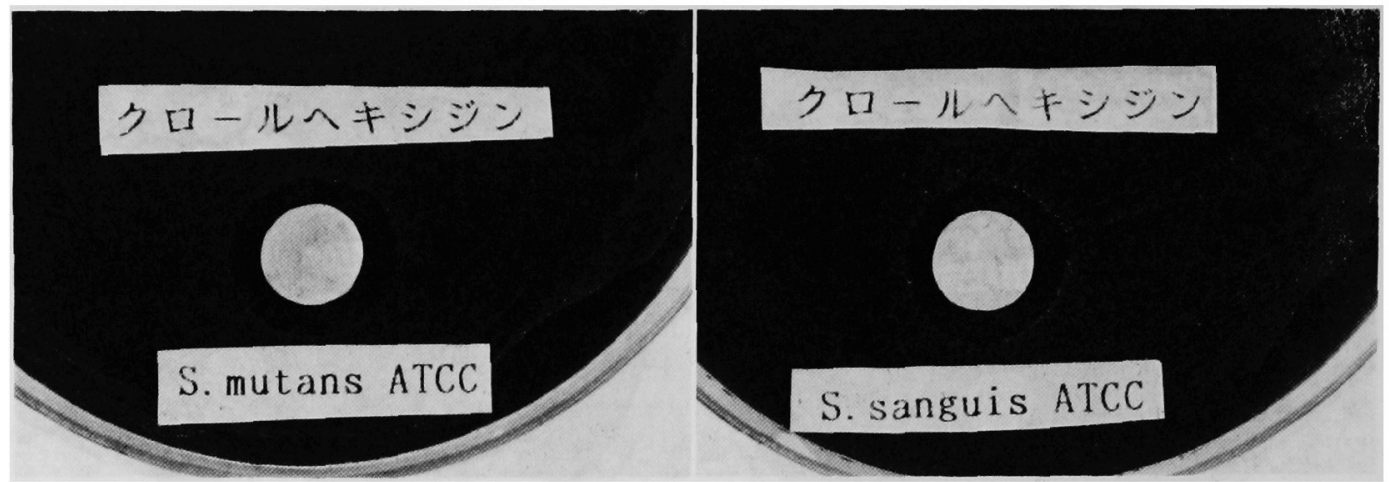

困 2 クロールヘキシジン添加による床用レジンの抗菌性の例

表 5 薬剤添加による林用レジンの抗菌性

\begin{tabular}{|c|c|c|c|}
\hline \multirow[b]{2}{*}{ 菌䔆 } & \multicolumn{3}{|c|}{ 添 加 薬 棛 } \\
\hline & HY 剂 & タンニン酸 & $\begin{array}{l}\text { クロール } \\
\text { ヘキシジン }\end{array}$ \\
\hline S. mutans & - & - & + \\
\hline S. sanguis & - & - & + \\
\hline S. oralis & - & - & - \\
\hline S. mitis & - & - & + \\
\hline S. salivaries & - & - & + \\
\hline B. intermedius & - & - & + \\
\hline B. gingivalis & - & - & + \\
\hline Eubacterinem & - & - & H \\
\hline Peptostreptococias & - & - & + \\
\hline Fusobucterium. & + & - & + \\
\hline Veillonella & - & - & + \\
\hline A. viscosies & - & - & - \\
\hline C. albicans & - & + & + \\
\hline
\end{tabular}

albicans のみに抗菌性を示した. しかし，クロールへキ シジン添加では A. viscosus と S. oralis 除く供試菌に 対して抗菌性を示した.

\section{IV. 考察}

有床義歯装着後口腔内には種々の変化が生じるが, と りわけ義歯装着により口腔内の環境が変化し, 支台歯へ プラークの付着を引き起こすようになり，それに伴い支 台歯がう蝕や歯周疾患に罹患し，支台歯在袁失すること は，有床義歯を装着しなくなる原因の 1 つであることは 過去の報告14)からも明白である. また, 床用レジン内面 に付着するいわゆるデンチャープラークについても，床 下粘膜に義歯性口内炎を惹起し, 快適な義歯装着を阻害 ナる ${ }^{15)}$.

このように, 有床義歯装着後の支台歯あるいは義歯床
内面へのプラーク付着は種々の問題を生じ，有床義歯装 着者におけるプラークコントロールは臨床上特に重要で ある. 有床義歯におけるプラークコントロールには，歯 プラシなどによる支台歯や義歯の機械的清掃 法のほか に，近年では義歯洗浄剤を用いた義歯の化学的清掃法も 行われている15).

一方, 最近增加しつつある高㱓者では，支台歯に対す る機械的清掃法は十分に行えないものと考えられる. そ こで，義歯自体に抗菌性を持たせ，プラークコントロー ルを容易にしようとする試みも行われている6). しかし， これまでの床用レジンや粘膜調整材の抗菌性についての 検討では，主に義歯性口内炎を対象として C. albicans や 2, 3 の菌種についてのみ行われており, う蝕や歯周 疾患に関連する細菌に対してはほとんど検討されていな W.

そこで今回われわれはこの点を考慮し，まず床用レジ ン自体の口腔内主要構成細菌種に対する抗菌性について 検討した.

本実験ではう虽関連細菌 ${ }^{16)}$ として, S. mutans, S. sanguis, S. mitis, S. oralis, S. salivalius, 歯周炎関連細菌 ${ }^{17)}$ として, B. intermedius, B. gingivalis, Eubacterium, Peptostreptococcus, Fusobacterium, Veillonella, A. viscosus を，義歯性口内炎関連細菌 ${ }^{18)}$ として C. albicans を 用いた.

抗菌性試験の結果, 重合直後のレジンで抗菌性を示す ものは, アクロン MC を除いてすべて常温重合型レジ ンであった. 佐藤ら ${ }^{19)}$ も修復用レジンの抗菌性を検討し たところ,コンポジットレジンにはあまり抗菌性はみら れなかったが, 常温重合型レジンにおいて抗菌性が強い ことを報告している，常温重合型レジンは残留モ/マー が多いと報告20)されており，このモノマーによって抗菌 性が発揮されたものと考えられる19). また, 常温重合レ 
ジンにおいては水中浸漬によって残留モノマーが水中に

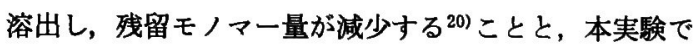
水中浸漬によって抗菌性が低下したことからも，抗菌性 は残留モノマーの溶出によるものと考えられる。

このように, 特定の菌種にしか抗菌性を示さないこ と，加熱重合レジンではほとんど抗菌性が認められない こと，抗菌性をある程度示した常温重合レジンでも水中 浸漬により抗菌性が低下すること，抗菌性の主体が流出 するモ/マーによるものと考えられることなどから，床 用レジン自体に長期的な抗菌性は期待できない，このよ うなことから，義歯の製作を考えた場合，加熱重合レジ ンあるいは表面滑沢硬化材に抗菌性を付与することが臨 休上有利であると考えられ，Addy ら5)の報告のように 本実験の目的のためには薬剤を加熱重合レジンに添加し て抗菌性を付与することが望ましいと思われる.

このような観点から，現在まで歯科において使用され ており, 安全性についても問題のない薬凧の中から床用 レジンに対する添加薬剤として, 支台歯のう蝕や歯周炎 に対して効果があるといわれている HY 㓮12,22) と, 義 歯性口内炎に対して効果があるといわれているタンニン 酸6), さらに, 従来から床用レジンの添加薬剈として用 いられているクロールヘキシジン2,5,7,10) 添加による抗菌 性について検討した. その結果, 薬剤添加により抗菌性 を示すようになり，特にクロールヘキシジンの添加によ り S. oralis と A. viscosus を除くすへてての供試菌に対し て抗菌性を示すようになった. この結果から, 今回検討 を行った薬㓮の中ではクロールヘキシジンが最も良い添 加薬椷と考えられた. 竹村ら ${ }^{23)}$ は Bis-GMA 系複合レジ ンにクロールヘキシジンを $0.5,1$ および $1.7 \%$ 添加 したところ, S. mutans, S. sanguis, A. viscosus に対 していずれの含有量においても抗菌性を示したと報告し ており，われわれの結果と合せクロールヘキシジンがレ ジンへの添加薬剤として優れた抗菌性を示すことがわか る. ただし，A. viscosus に対して抗菌性を示さなかった 点については，用いたレジンの相違などが関係している と考えられるが明確ではない，同様に床用レジンあるい はコンポジットレジンへのクロールヘキシジン添加によ り, Lamb ら ${ }^{7)}$ は C. albicans に対して, Addy) は Staphylococcus に対して, Jedrychowski ら ${ }^{24)}$ は Streptococcus viridans, Streptococcuc pyogenes, Streptococcus mutans, Escherichia coli, Lactobacillus acidophilus に対して抗 菌性を示すことを報告している.このように，われわれ の報告を含めてこれまでの報告から，クロールヘキシジ ンは優れた抗菌性を有していることがわかる.

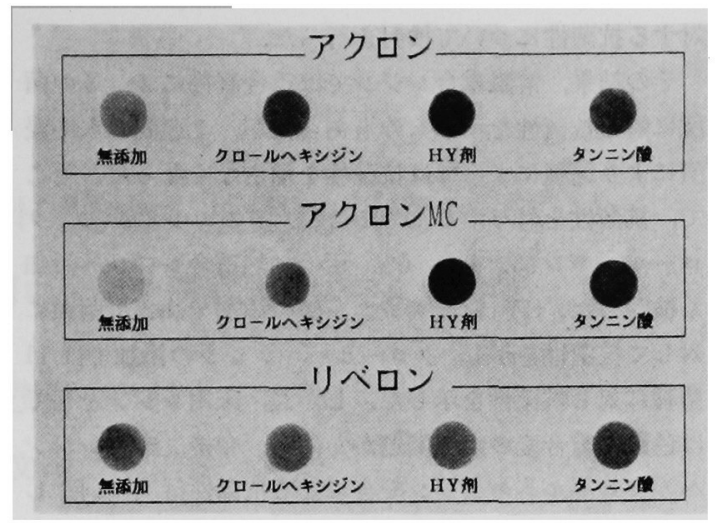

図 3 薬刘添加による重合後の床用レジンの色調変化

しかし,このように抗菌性を示すようになったが他に いくつかの問題が認められた. すなわち, 図 3 に示すよ うに薬剂を添加して重合した場合, 常温重合レジンを除 いてレジンの色調が大きく損なわれており, 特に HY 材 とタンニン酸では茶褐色に変色し, 床用レジンとしては 満足すべきものではなかった. また, クロールヘキシジ ンでは変色は少なかったものの, 重合体は重合が不完全 で軟性を示していた. クロールヘキシジン添加による床 用レジンの物性については, Addy ら ら)は加熱重合およ び常温重合の床用レジンにクロールヘキシジンを添加し た場合、ヌープ硬さおよび曲げ強さなどが低下し，床用 レジンとしては使用できないが，リベース材やリライニ ング材としては有効であると述べている.

今回はクロールヘキシジン添加床用レジンの口腔内主 要細菌に対する抗菌性を知るために, 重合直後の抗菌性 についてのみ検討したが, 実際の使用を考えた場合, 長 期にわたる抗菌性についても検討する必要があると思わ れる. この点について Addy ${ }^{10)}$ は 10\% クロールヘキシ ジン添加床用レジンでは 16 週以上にわたって水中への クロールヘキシジンの溶出が認められたと報告し，また $10 \%$ クロールヘキシジンと $30 \%$ 蒸留水を含有する常温 重合型床用レジンからの 140 日以上のクロールヘキシジ ンの溶出を報告5)している.

以上の上うに, 今回用いた薬風の添加量では, 床用レ ジンとしての満足すへき条件が得られなかった. 今後, これらの点を考慮した抗菌性の検討が必要であると思わ れる.

\section{V. 結 論}

今回われわれは, 床用レジンの口腔内主要構成細菌に 
対する抗菌性について検封を行った.

その結果, 常温重合レジンでは重合值後に 2,3 の菌 種に対し抗菌性を示すものもあったが，1 週間の水中浸 漬により菌種によっては抗菌性を示さなくなった. そこ で，抗菌性を付与するため $\mathrm{HY}$ 材，タンニン酸およびク ロールヘキシジンを各 $5 \%$ ずつ加熱重合レジンへ添加 し検討した. HY 材とタンニン酸の添加では各 1 菌種に 対して抗菌性を示し,クロールヘキシジンの添加では 11 菌種に対し抗菌性を示した. しかし, 床用レジンとして は色調や重合度の点で問題があった. 今後, 床用レジン へのクロールヘキシジン配合による抗菌性付与に関 し て, 添加量を変えた場合の薬剤の溶出, 機械的性質や抗 菌性への影響などについて検討するとともに，他の薬剤 についても検討する必要があると考えられる.

本論文の要旨は第 79 回日本補緅歯科学会学術大会 (昭和 63 年 5 月 27 日，東京）において発表した.

クロールヘキシジンを提供していただいた（株）丸石製薬に感 謝いたします.

\section{文献}

1）渡辺義梮 : 弾性裏装材における細菌の付着性に関する研 究, 九州龇会誌, $37: 201 \sim 214,1983$.

2) Addy,M. and Handley, R. : The effects of the incorporation of chlorhexidine acetate on some physical properties of polymerized and plasticized acrylics, J Oral Rehabili, $8: 155 \sim 163,1981$.

3) Zitz, A., Gedalia, I. and Grajower, R. : Addition of fluoride compounds to acrylic resin plates: bending strength and fluoride release, J Oral Rehabili, $8: 37 \sim$ $41,1981$.

4) 山賀 保, 近川 洋, 金 道栄ほか: タンニン・フッ化物 配合剂を配合した義歯床内充填材料に関する研究, 補緅誌, $31: 1499 \sim 1505,1987$.

5) Addy, M. and Thaw, M.: In vitro studies into the release of chlorhexidine acetate, prednisolone sodium phosphate, and prednisolone alcohol from cold cure denture base acrylic, J Biomed Mater Res, $16: 145 \sim$ $157,1982$.

6）田中孝明 : Candida albicans の有床義歯裹装材への吸着 に関するタンニン酸の効果, 日大口腔科学, $14: 111 \sim 122$, 1988.

7) Lamb, D.J. and Martin, M.V. : An in vitro and in vivo study of the effect of incorporation of chlorhexidine into autopoly merizing acrylic resin plates upon the growth of Candida albicans, Biomaterials, $4: 205 \sim 209$, 1983.

8) Douglas, W.H. and Walker, D.M. : Nystatin in denture liners-an alternative treatment of denture stomatitis, Br Dent J, $135: 55 \sim 59,1973$.

9) Thomas, C.J. and Nutt, G.M. : The in vitro fungicidal properties of Visco-gel, alone and combined with nystatin and amphotericin B, J Oral Rehabili, $5: 167 \sim$ 172, 1978.

10) Addy, M. : In vitro studies into the use of denture base and soft liner materials as carriers for drugs in the mouth, J Oral Rehabili, $8: 131 \sim 142,1981$.

11) Quin, D.M. : The effectiveness, in vitro, of micronazole and keteconazole combined with tissue conditioners in inhibiting the growth of Candida albicans, J Oral Rehabili, $12: 177 \sim 182,1985$.

12）山賀澧一：HY 材の基磷的勃果とその適用，日歯内源誌, $1: 17 \sim 24,1980$.

13）山本宏治、山内六男, 松本 敦ほか：口腔細菌に対する合 着用セメントの抗菌性, 日歯保誌, $30: 1551 \sim 1555,1987$.

14）雨森 洋, 奥野正孝, 郡司和彦, 他: 部分床義歯の予後に 関する臨床的研究 第 2 報 部分床義歯の使用状態につい て, 補緅誌, $12: 155 \sim 171,1968$.

15）浜田泰三 : デンチャープラークコントロール, 永末書店, 京都, 1983.

16）大䳋 隆: 動物実験におけるう蝕の誘発, 浜田茂幸編 う 蝕と畨周病, vol. 2, 1 29, 日本歯科評論, 東京, 1982.

17） Genco, R.J. and Mergenhagen, S.E. 編, 浜田茂幸, 他: 歯周病の科学, 第 1版, 2 21, 医歯薬出版, 東京, 1985 .

18) Davenport, J.C. : The oral distribution of Candida in denture stomatitis, Br Dent J, $129: 151 \sim 156,1970$.

19）佐藤尚毅，村上淳子，香西淑子ほか：歯冠修復材の抗菌性 について, 日歯保誌, $25: 442 \sim 452,1982$.

20）奥野善彦，丸岡寛昭，野首孝唰ほか：注入型レジンに関す る基礎的研究, 阪大歯誌, $17: 46 \sim 55,1972$.

21）佐野敬一：鉤歯の義菊側隣接面におけるタンニン・フッ化

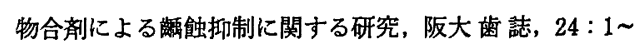
20, 1979.

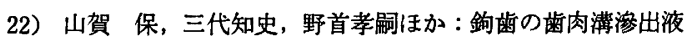
量に関する臨床的研究 (第 1 報) タンニン・フッ化物合剤 の影響について, 補経誌, $26: 999 \sim 1006,1982$.

23）竹村金造, 阪本有三, Michal Staninec ほか : 一種の BisGMA 系複合レジンの抗菌性とクロールヘキシジン配合に よる抗菌効果, 日歯保誌, $26: 540 \sim 547,1983$.

24) Jedrychowski, J.R., Caputo, A.A. and Kerper, S. : Antibacterial and mechanical properties of restorative materials combined with chlorhexidines, J Oral Rehabili, $10: 373 \sim 381,1983$. 